\title{
Study of less widespread and rare Georgian wine grape varieties
}

\author{
L. Mamasakhlisashvili and L. Ujmajuridze \\ LEPL Scientific-Research Center of Agriculture, Marshal Gelovani Avenue N 6, 0159 Tbilisi, Georgia
}

\begin{abstract}
The genetic biodiversity of the Georgian genome of vine is a resource that creates Georgian viticulture - winemaking basis. According to its species diversity Solomon Cholokashvili Jigaura National International Category Collection GEO 038 of Mtskheta Municiality is really very interesting. On the background of the climate global changes it is necessary to complexly re-study the less widespread and rare grape varieties - according to fenological, chemical and enocarpological characteristics, and others, to spread them on their wide range - for the purpose of diversity of entrepreneurial varieties. In addition, information received as a result of the research will be used in variety breeding, as the original material for the parent couple's target selection.
\end{abstract}

The study of the species for research was performed in field and laboratory conditions by complex using of different research methods.

The study included study of rarely spread - Saperavi Budeshurisebri (Kakheti Region) and rare vine species - Ikaltos Tsiteli, Ingilouri, Zaqatalis Tetri [2] (Kakheti region), Qvelouri (Imereti region) and Mauri Tetri [3] (Guria region) during the vegetation period of 2018.

Within each breeding, for calculation phenological phases, BBCH scales were used [1] (Lorenz et al. 1994). Observation included phases of bud burst, opening, development of the leaf (from 1 to 14 leaf) blossoming, ripening and leaf falling. The study has begun from the period of bud burst (April 4) and ended at the end of the leaf falling period (November 15), which was carried out with a 7-day interval. Fertilization of basal buds (1-3 buds) [5] has been studied, according to $\mathrm{kg} / 1 \mathrm{~m}^{2}$ in OIV (2007).

COST action FA-1003 was used for enocarpological research within the project "East-West collaboration for Grapevine Diversity Exploration and Mobilization of Adaptive Traits for Beeding" the phenotypic method for the encyclopedic assessment of adapted varieties (Rustioni et al. 2014) in accordance with methodics. The 9 varieties of grape species (for each breed repeated 3) have been analyzed. The parameters were studied in each repetition for carpological analysis: grape species and grain weight, sizes of grain, weight of skin and grape pip, number of pips in the grain. Was identified quantitative parameters of common anthocyanins and polyphenols in the skin and grape pip of the fetus and grape juice characteristics: common soluble substance with digital refractometer, acidity of grape juice with titration method $0.1 \mathrm{NaOH}$ and grape juice $\mathrm{pH}$ indicator.

As a result of observation, fertilization of basal buds (1-3 buds) of the study varieties were average (OIV 155). Harvest $\mathrm{kg} / 1 \mathrm{~m}^{2}$, Saperavi Budeshurisebri, Ikaltos Tsiteli [4] and Kvelouri were high (OIV 504), and Zakatalis Tetri, Ingilouri and Mauri Tetri - the average. Duration of the vegetation period is important for the realization of the breed. I was determined from the bud opening to its ripening: Ingilouri - 153 days; Saperavi Budeshurisebri, Ikalto Red - 154; Zakatali White - 156; Kvelouri and Mauri White - 159 days.

Sugar content in the grape juice indicators (Fig. 1) was varying 23.2-25.2 (Mauri Tetri-Saperavi Budeshurisebri [4]); Common acidity 6.2-7.25 g/l ( Ingilouri-Mauri Tetri). pH indicator between 3.33-3.61 (Mauri TetriZakatalis Tetri).

As shown in the table, Ikaltos Tsiteli of the the redseeded varieties have a relatively large weight of $2.1 \mathrm{~g}$ of grains, the weight of one seed is more than $-0.6 \mathrm{~g}$, the number of pips in a single seed is -2.2 , the width of the grain and the weight of the bunches, than Qvelouri and Saperavi Budeshurisebri.

The big weight, length and width of the grain, from the white varieties has the Zaqatalis Tetri, while the Mauri Tetri is distinguished by great weight of the bunches. As a result of research, the difference of carpologic indicators was revealed.

The general content of anthocyanins for Saperavi Budeshurisebri - 1198.7 (mg/kg grapes), Qvelouri - 540.7, Ikaltos Tsiteli - 293.1 (mg/kg grapes). Polyphonols were revealed to be more for Qvelouri breed in the skin extract (Fig. 2) - 2070.4, than Ikaltos Tsiteli - 1982.9 and Saperavi Budeshurisebri - 1643.3 ( $\mathrm{mg} / \mathrm{kg}$ grapes). Common polyphonols were also more in the grape pip extract in Qvelouri - 1348.2 (mg/kg grapes), compared with Saperavi Budeshurisebri - 949.85 and Ikaltos Tsiteli -724.2 ( $\mathrm{mg} / \mathrm{kg}$ grapes). From the white grape varieties the content of polyphonols in the skin extract was for Ingilouri - 1044.4 (mg/kg grapes), Mauri Tetri - 560, Zaqatalis Tetri -480.53 ( $\mathrm{mg} / \mathrm{kg}$ grapes). Content of extracted polyphonols from the pip of the grape is lower compared with the skin (Fig. 2). Ingilouri - 690.3 (mg/kg grapes), Mauri Tetri 575 , Zaqatalis Tetri - 109.4 (mg/kg grapes).

As the studies have shown, the common polyphonols in the red grape varieties are: Saperavi Budeshurisebri$2593.15 \mathrm{mg} / \mathrm{kg}$ grapes, Ikalto Tsiteli - 2707.1 and 
Table 1. Carpological parameters of vine species.

\begin{tabular}{|l|l|c|c|c|c|c|c|c|}
\hline $\begin{array}{l}\text { Accession } \\
\text { name }\end{array}$ & $\begin{array}{l}\text { Berry color } \\
\text { (OIV descriptor) }\end{array}$ & $\begin{array}{c}\text { Berry } \\
\text { weight }(\mathrm{g})\end{array}$ & $\begin{array}{c}\text { Skin } \\
\text { weight }(\mathrm{g})\end{array}$ & $\begin{array}{c}\text { Number of } \\
\text { seeds/berry }\end{array}$ & $\begin{array}{c}\text { Weight of 1 } \\
\text { seed (g) }\end{array}$ & $\begin{array}{c}\text { Berry } \\
\text { length (mm) }\end{array}$ & $\begin{array}{c}\text { Berry } \\
\text { width (mm) }\end{array}$ & $\begin{array}{c}\text { Bunch } \\
\text { weight (g) }\end{array}$ \\
\hline Qvelouri & Blue Black & 1.7 & 0.43 & 2.2 & 0.1 & 1.1 & 1.04 & 193.6 \\
\hline Mauri Tetri & Green Yellow & 2.1 & 0.45 & 2.4 & 0.13 & 1.1 & 1.1 & 247.5 \\
\hline Ingilouri & Green Yellow & 1.8 & 0.3 & 1.8 & 0.1 & 1.1 & 1.1 & 118.15 \\
\hline Ikaltos Tsiteli & Blue Black & 2.1 & 0.6 & 2.2 & 0.1 & 1.2 & 1.2 & 194.21 \\
\hline Zaqatalis Tetri & Green Yellow & 3.0 & 0.5 & 1.9 & 0.1 & 1.4 & 1.3 & 175.36 \\
\hline $\begin{array}{l}\text { Saperavi } \\
\text { Budeshurisebri }\end{array}$ & Blue Black & 1.6 & 0.4 & 1.5 & 0.1 & 1.24 & 0.9 & 157.33 \\
\hline
\end{tabular}

\section{Chart Title}

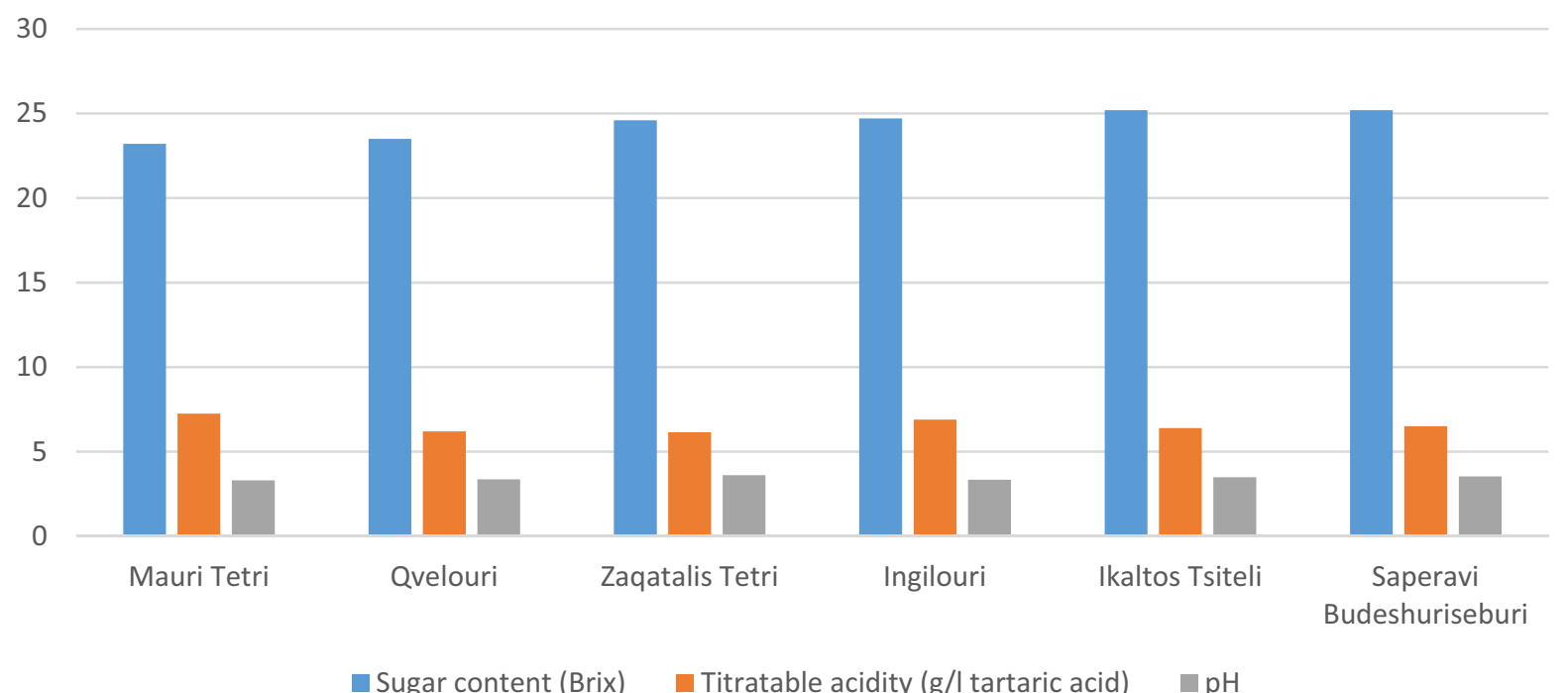

Figure 1. Grape juice indicators.

2500

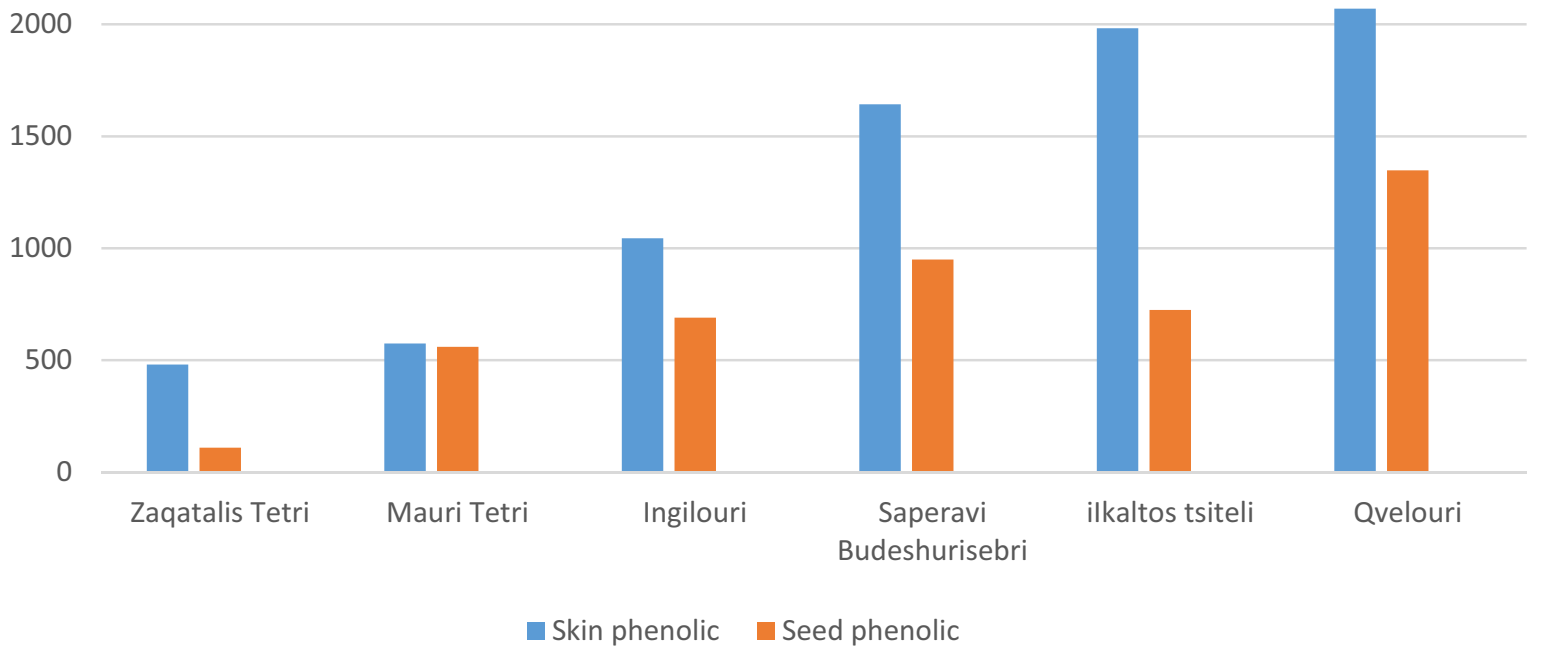

Figure 2. Polyphenols in the skin of the fruit and pip's extract (mg/kg grapes). 
Qvelouri - 3418.57 mg/kg grapes. The common polyphonols in the white grape varieties are: Zaqatalis Tetri - 589.96, Mauris Tetri - 1135 and Ingilouri - $1734.7 \mathrm{mg} / \mathrm{kg}$ grapes.

The diversity of researched parameters have been identified in the study of less widespread and rare Georgian wine species, which is due to the peculiarity of the breed, its genetic potential and environmental factors.

Study of complex - fenologic, grape juice and enocarpological characteristics of the grape varieties provides some kind of information about the breed, which can be used for theoretical and practical purposes. Characteristics for the evaluation of the qualitative potential of each species-total anthocyanins, polyphenols, carpological and other is important both for the characterization of the variety and for the optimization of winemaking technologies.

\section{References}

[1] D.H. Lorenz, K.W. Eichhorn, H. Blei-Holder, R. Klose, U. Meier, E. Weber, Vitis. Enol. Sci. 49, 66 (1994)

[2] D. Tabidze, Technika da shroma. Tbilisi (in Georgian) 195, 416 (1954)

[3] M. Ramishvili, Technika da shroma. Tbilisi, (in Georgian) 63 (1948)

[4] L. Ujmajuridze, G. Kakabadze, L. Mamasakhlisashvili, Tbilisi (in Georgian) 166, 337 (2018)

[5] OIV, Descriptors for Grapevine Cultivars and Vitis Spesies (Office International de la vigneet du vin (O.I.V.). Paris, France, 2007), p. 1

[6] L. Rustioni, D. Maghradzr, L. Mamasakhlisashvili, G. Savin, L. Ujmajurudze, E. Mauli, R. Bachilieri, O.Failla, et.al., Vitis. 53, 219 (2014) 